\title{
Proximate and Phytochemical Analysis of Seed Coat from P. sumantranse (Little Millet)
}

Sandeep Raja Dangeti ${ }^{1,2 *}$, S Karthikeyan², Githa R Kumar ${ }^{2}$ and Sarth Desai ${ }^{2}$

${ }^{1}$ Biomedical Informatics, New No: 42, 2nd Main Road, Adayar, Chennai, I600020, India

${ }^{2}$ School of Biological Sciences and Technology, VIT University, Vellore, Tamilnadu, 632014, India

\begin{abstract}
Little millets ( $P$. sumantranse) has health benefits, and as well as economic importance. The rural farmers at Javadhu hills near Vellore district were exploited by the retailers in processing of little millets. We took this problem, in removing the seed coat from this seed in economic way using enzyme based technology. In this process, we concentrated in proximate and phytochemical analysis of the seed coat for better understanding of its chemical properties, prior to enzymatic treatment. $100 \mathrm{gms}$ of seed coat is removed from the seed through mechanical treatment and we carried the proximate analysis, i.e. reducing sugar content, total carbohydrate, elemental analysis, moisture content, total fat, total protein, total fiber content and Total ash. The results found to be total carbohydrate- $47.85 \mathrm{gms} / 100 \mathrm{gms}$ of seed coat, total protein-6.26 gms $/ 100 \mathrm{gms}$, total fat- $2.03 \mathrm{gms} / 100 \mathrm{gms}$, ash content (by dry basis) $-20.51 \mathrm{gms} / 100 \mathrm{gms}$ and moisture content to be $10.16 \%$. The phytochemical analysis showed that flavanoids $0.18 \mathrm{gms} / 100 \mathrm{gms}$ and phenolics $0.32 \mathrm{gms} / 100 \mathrm{gms}$.
\end{abstract}

Keywords: Little Millet; Phytochemical analysis; Alkaloids

\section{Background}

The transformation of agriculture to more productive systems has often been accompanied by increased production of a fewer crops species. Concurrently, the area and production of a great diversity of traditional crops have declined. Yet in many parts of the world, these traditional crops play an important role in maintaining stable and sustainable forms of agriculture. One such traditional group of cereal crops is the little millets. (The millets considered here are those being cultivated in the subtropical and tropical areas of the Old World), little millet (Panicum sumatrense) the grains of little millets, being nutritionally superior to rice and wheat, provide cheap proteins, minerals and vitamins to poorest of the poor, where the need for such ingredients is the maximum. Practically devoid of grain storage pests, the little millets have indefinite storage life [1]. The untapped grain yield potential coupled with nutritional superiority makes the little millets potential future food crops, particularly in the more difficult rain fed areas. Little millets have high nutritional and medicinal value, high dietary fibre content, easy digestibility and other uses. It has medicinal values in the management of diabetes and lowering lipids esp. cholesterol. Best remedy for obese, diabetic, elders and flat belly aspirants. The rural farmers at Javadhu hills near Vellore district were exploited by the retailers in processing of the seeds from little millets. The retailers used to cost around $1.5 \$ / \mathrm{kg}$ for processing of seed. The farmers are always exploited by the middle man, as they do not have accessibility to technology. We taken this problem as a serious issue and we started developing an enzyme based technology [2-4], which could decrease the processing cost of the seeds. In the article, we are providing the chemical composition and nutrient value of the seed coat from the little millet through proximate and phytochemical analysis, by analyzing the different previous studies [5-7].

\section{Methodology}

\section{Preparation of sample}

Seeds are taken from the farm which is then cleaned, washed and dried. The seed coat of about 100 gms is collected by simple mechanical treatment of the seeds.

\section{Proximate analysis}

Estimation of reducing sugar: The reducing sugar is estimated by di-nitro salicylic acid method [8,9]. In this method, weigh $100 \mathrm{mg}$ of the sample and extract the sugars with hot $80 \%$ ethanol twice $(5 \mathrm{ml}$ each time). Collect the supernatant and evaporate it by keeping it on a water bath at $80^{\circ} \mathrm{C}$. Add $10 \mathrm{ml}$ water and dissolve the sugars. Pipette out $0.5-3 \mathrm{ml}$ of the extract in test tubes and equalize the volume to $3 \mathrm{ml}$ with water in all the tubes. Add $3 \mathrm{ml}$ of DNS reagent. Heat the contents in a boiling water bath for $5 \mathrm{~min}$. When the contents of the tubes are still warm, add $1 \mathrm{ml}$ of $40 \%$ Rochelle salt solution. Cool and read the intensity of dark red colour at $510 \mathrm{~nm}$. Run a series of standards using glucose $(0-500 \mu \mathrm{g})$, and plot a graph.

Estimation of total carbohydrate: The total carbohydrate present in seed coat is estimated by phenol- sulphuric acid method [8,9]. In this method, weigh $100 \mathrm{mg}$ of the seed coat (sample) into a boiling tube. Hydrolyze by keeping it in a boiling water bath for three hours with 5 $\mathrm{ml}$ of $2.5 \mathrm{~N} \mathrm{HCl}$, and cool to room temperature. Neutralize it with solid sodium carbonate, until the effervescence ceases. Make up the volume to $100 \mathrm{ml}$ and centrifuge. Pipette out $0.2,0.4,0.6,0.8$ and $1 \mathrm{ml}$ of the working standard into a series of test tubes. Pipette out 0.1 and $0.2 \mathrm{ml}$ of the sample solution in two separate test tubes. Make up the volume in each tube to $1 \mathrm{ml}$ with water. Set a blank with $1 \mathrm{ml}$ of water. Add 1 $\mathrm{ml}$ of phenol solution to each tube. Add $5 \mathrm{ml}$ of $96 \%$ sulphuric acid to each tube and shake well. After $10 \mathrm{~min}$, shake the contents in the tubes and place in water bath at $25-30^{\circ} \mathrm{C}$ for $20 \mathrm{~min}$. Read the colour at 490 $\mathrm{nm}$. Calculate the amount of total carbohydrate present in the sample solution using the standard graph.

*Corresponding author: Sandeep Raja Dangeti, Biomedical Informatics, New No: 42, 2nd Main road, Adayar, Chennai-600020, India, Tel: +91 860849 1314; E-mail: sandeepraja@rocketmail.com

Received march 9, 2013; Accepted April 15, 2013; Published April 18, 2013

Citation: Dangeti SR, Karthikeyan S, Kumar GR, Desai S (2013) Proximate and Phytochemical Analysis of Seed Coat from P. sumantranse (Little Millet). Biochem Anal Biochem 2: 134. doi:10.4172/2161-1009.1000134

Copyright: (c) 2013 Dangeti SR, et al. This is an open-access article distributed under the terms of the Creative Commons Attribution License, which permits unrestricted use, distribution, and reproduction in any medium, provided the original author and source are credited. 
Moisture content: The moisture content of these seeds was determined in triplicate by drying at $120^{\circ} \mathrm{C}$ to constant dry weight in a hot-air oven [8].

Total fat: The total fat content was determined by extraction of 2.0$2.5 \mathrm{~g}$ of dry ground sample for $12 \mathrm{~h}$ in a Soxhlet with petroleum ether, and removed the solvent by rotary evaporator, then dried the sample in hot air oven at $100^{\circ} \mathrm{C}$ for about $1 \mathrm{~h}$ to allow the ether evaporate $[4,8]$.

Total protein: The total protein content in the seed coat is estimated by Lowry's method. Different dilutions of BSA solutions are prepared by mixing stock BSA solution $(1 \mathrm{mg} / \mathrm{ml})$ and water in the test tube, as given in the table. The final volume in each of the test tubes is $5 \mathrm{ml}$. The BSA range is $0.05-1 \mathrm{mg} / \mathrm{ml}$. From these different dilutions, pipette out $0.2 \mathrm{ml}$ protein solution to different test tubes and add $2 \mathrm{ml}$ of alkaline copper sulphate reagent (analytical reagent). Mix the solutions well. This solution is incubated at room temperature for 10 mins. Then add $0.2 \mathrm{ml}$ of reagent Folin Ciocalteau solution (reagent solutions) to each tube, and incubate for $30 \mathrm{~min}$. Zero the colorimeter with blank and take the optical density (measure the absorbance) at $660 \mathrm{~nm}$. Plot the absorbance against protein concentration to get a standard calibration curve. Check the absorbance of unknown sample, and determine the concentration of the unknown sample using the standard curve plotted above $[8,10]$.

Estimation of crude fiber: Extract $2 \mathrm{~g}$ of ground material of seed coat with ether or petroleum ether to remove fat (Initial boiling temperature $35-38^{\circ} \mathrm{C}$ and final temperature $52^{\circ} \mathrm{C}$ ). If fat content is below $1 \%$, extraction may be omitted. After extraction with ether, boil $2 \mathrm{~g}$ of dried material with $200 \mathrm{ml}$ of sulphuric acid for 30 min with bumping chips. Filter through muslin and wash with boiling water, until washings are no longer acidic. Boil with $200 \mathrm{ml}$ of sodium hydroxide solution for $30 \mathrm{~min}$. Filter through muslin cloth again and wash with $25 \mathrm{ml}$ of boiling $1.25 \% \mathrm{H}_{2} \mathrm{SO}_{4}$, three $50 \mathrm{ml}$ portions of water and $25 \mathrm{ml}$ alcohol. Remove the residue and transfer to ashing dish. Dry the residue for 2 $\mathrm{h}$ at $130 \pm 2^{\circ} \mathrm{C}$. Cool the dish in desiccators. Ignite for $30 \mathrm{~min}$ at $600 \pm$ $15^{\circ} \mathrm{C}$. Cool in desiccators [8].

Ash content: In this, dry ashing method is used. Dry ashing procedures use a high temperature muffle furnace capable of maintaining temperatures of between 500 and $600^{\circ} \mathrm{C}$. The seed coat sample of 50 gms is taken and weighed before keeping for drying in muffle furnace, and after ashing to determine the concentration of ash present. The ash content can be expressed on either a dry basis [8].

\section{\%ASH (DRY BASIS) $=$ Mash X100 / Mdry}

Elemental analysis: Samples are prepared as by taking 2 gms of samples (seed coat obtained by different solvent treatment), and add $10 \mathrm{ml}$ of conc. nitric acid. Transfer them in to crucibles and keep them inside furnace at 200 degrees. Take out the ash formed in the crucibles. Dilute them with water and filter the supernatant. Standards are prepared as per, and readings are noted with the help of Atomic absorption spectroscopy [8].

\section{Phytochemical analysis}

Qualitative analysis: The methanolic extract of the seed coat is prepared by transferring in to methanol in $(40 \% \mathrm{v} / \mathrm{w})$, and keeping it for 2 hours. Now, the methanol is removed and washed twice with distilled water. Now, the extract is dried and dissolved at $1 \mathrm{gm} / 10 \mathrm{ml}$ and analysis was carried out [8].

Alkaloids: For the detection of presence of Alkaloid, Wagner's was performed, where initially solvent free extract $50 \mathrm{mg}$ was mixed with few $\mathrm{ml}$ of dilute hydrochloric acid and then filtered, the filtrate is used for testing the presence of alkaloids. To a few $\mathrm{ml}$ of filtrate, a few drops of Wagner's reagent were added by the side of the test tube. A reddish brown precipitate indicates the presence of alkaloids [8].

Glycosides: $50 \mathrm{mg}$ of extract was mixed with few $\mathrm{ml}$ of conc. hydrochloric acid for 2 hours on water bath and then filtered; the filtrate was used for testing the presence of glycosides by legal's test. $0.5 \mathrm{ml}$ of filtrate was dissolved in pyridine, and then sodium nitroprusside solution was added and made alkaline using $10 \%$ sodium hydroxide. Pink color indicates the presence of glycosides [8].

Saponins: The extract $(50 \mathrm{mg})$ was diluted in distilled water, and then made up to $20 \mathrm{ml}$. The suspension was shaken in a graduated cylinder for $15 \mathrm{~min}$. A $2 \mathrm{~cm}$ layer of foam indicates the presence of saponins [8].

Oil: A small quantity of extract was pressed between two filter papers; oil stain on the paper indicates the presence of fixed oil [8].

Phenolics and tanins: The extract $(50 \mathrm{~g})$ was dissolved in $5 \mathrm{ml}$ of distilled water and filtered. Filtrate obtained was used for ferric chloride test. To $0.5 \mathrm{ml}$ of filtrate, few drops of neutral $5 \%$ ferric chloride solution were added. A dark green color indicates the presence of phenolic compounds [8].

Lead acetate: The extract was dissolved in distilled water and to this, $3 \mathrm{ml}$ of $10 \%$ lead acetate solution was added, a bulky white precipitate indicates the presence of phenolic compounds [8].

Gum test: The extract $(100 \mathrm{mg})$ was dissolved in $10 \mathrm{ml}$ of distilled water, and to this solution, $25 \mathrm{ml}$ of absolute alcohol was added with constant stirring. White or cloudy precipitate indicates the presence of gums [8].

Erpenoids: Salkowski Test: To $5 \mathrm{ml}$ of each extract was mixed in $2 \mathrm{ml}$ of chloroform and $3 \mathrm{ml}$ of conc. $\mathrm{H}_{2} \mathrm{SO}_{4}$ was carefully added form the sides of test tube. A reddish brown coloration of the interface was formed to show positive results for the presence of terpenoids [8].

Steroids: Liebermann test: To $2 \mathrm{ml}$ of acetic anhydride was added to $0.5 \mathrm{~g}$ methanolic extract of each sample with $2 \mathrm{ml} \mathrm{H}_{2} \mathrm{SO}_{4}$. The color changed from violet to blue or green in some samples, indicating the presence of steroids [8].

\section{Quantitative analysis}

Determination of total phenolic contents: The total phenol content in the methonolic extract of seed coat extract was determined spectrophotometrically using Folin-Ciocalteu method as described by Kujala et al. [9]. An aliquot of $1 \mathrm{ml}$ extract was mixed with $5 \mathrm{ml}$ of Folin-Ciocalteu reagent (previously diluted with water 1:10 v/v) and $4 \mathrm{ml}$ of Sodium carbonate $(7 \% \mathrm{w} / \mathrm{v})$, and shaken. The solution was allowed to stand for $30 \mathrm{~min}$ in dark at room temperature, after which absorbance was measured at $765 \mathrm{~nm}$ using a spectrophotometer. Gallic acid was used as a standard compound, in the range of 50 to $200 \mu \mathrm{g} /$ $\mathrm{ml}$ concentration to construct a standard curve. The amount of total phenolic was expressed as gallic acid equivalent (GAE) in milligram per gram dried extract [8].

Determination of flavanoids: The total flavonoids were determined using a colorimetric method, as described by Shiva et al. [10]. Briefly $0.1 \mathrm{ml}$ of the methonolic extract was diluted with $0.9 \mathrm{ml}$ of methanol Aliquots of diluted extracts $(0.5 \mathrm{ml})$ were added to test tubes and mixed 
with $0.1 \mathrm{ml}$ of $10 \%$ aluminum nitrate, $0.1 \mathrm{ml}$ of $1 \mathrm{M}$ aqueous potassium acetate and $4.3 \mathrm{ml}$ of methanol. After standing for $40 \mathrm{~min}$ at room temperature, the absorbance of the reaction mixture was measured at $415 \mathrm{~nm}$. Quercetin was used as a standard compound in the range of $50-200 \mu \mathrm{g} / \mathrm{ml}$ concentration to construct a standard curve. The amount of total flavonoids was expressed as quercetin equivalent in milligram per gram of dried extract $[8,11,12]$.

\section{Results}

\section{Proximate analysis}

At $510 \mathrm{~nm}$, the absorbance of total reducing sugar using DNSA method found to be zero, which indicates absence of reducing sugar in the seed coat. At $600 \mathrm{~nm}$, the OD for total carbohydrate is found to be 0.574 and concentration was observed to be $47.85 \mathrm{gms} / 100 \mathrm{gms}$, as shown in the figure $1 \mathrm{~A}$. The total protein as per Lowry's method shows OD of 0.67 at $600 \mathrm{~nm}$. This result in the concentration of protein in seed coat is found to be $6.26 \mathrm{gms} / 100 \mathrm{gms}$, as shown in figure 1B. The ash content of the seed coat is observed with the help of dry basis, it showed the mass of ash in dry basis as $10.25 \mathrm{gms}$ for $50 \mathrm{gms}$, and percentage of ash on dry basis is found to be $20.51 \%$. The total fat observed by

\begin{tabular}{|c|c|}
\hline Test & Results (gms/100 gms) \\
\hline Ash(dry method) & 20.51 \\
\hline Crude fat & 2.04 \\
\hline Crude protien & 6.26 \\
\hline Crude fibre & 13.08 \\
\hline Carbohydrate & 47.85 \\
\hline Moisture & 10.16 \\
\hline Iron(Fe) & 0.116 \\
\hline Calcium(Ca) & 0.05 \\
\hline Phosphorus(P) & 0.11 \\
\hline Nickel (Ni) & 0.01 \\
\hline Zinc $(\mathrm{Zn})$ & 0.048 \\
\hline Copper $(\mathrm{Cu})$ & 0.05 \\
\hline
\end{tabular}

Note: Results above shows concentration

Table 1: Proximate analysis of little millets ( $P$. sumantranse).

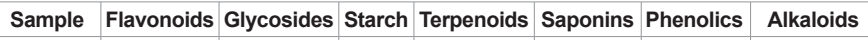
Little millet $\quad+$

Table 2: Qualitative Phytochemical analysis of seeds from $P$. sumantranse.
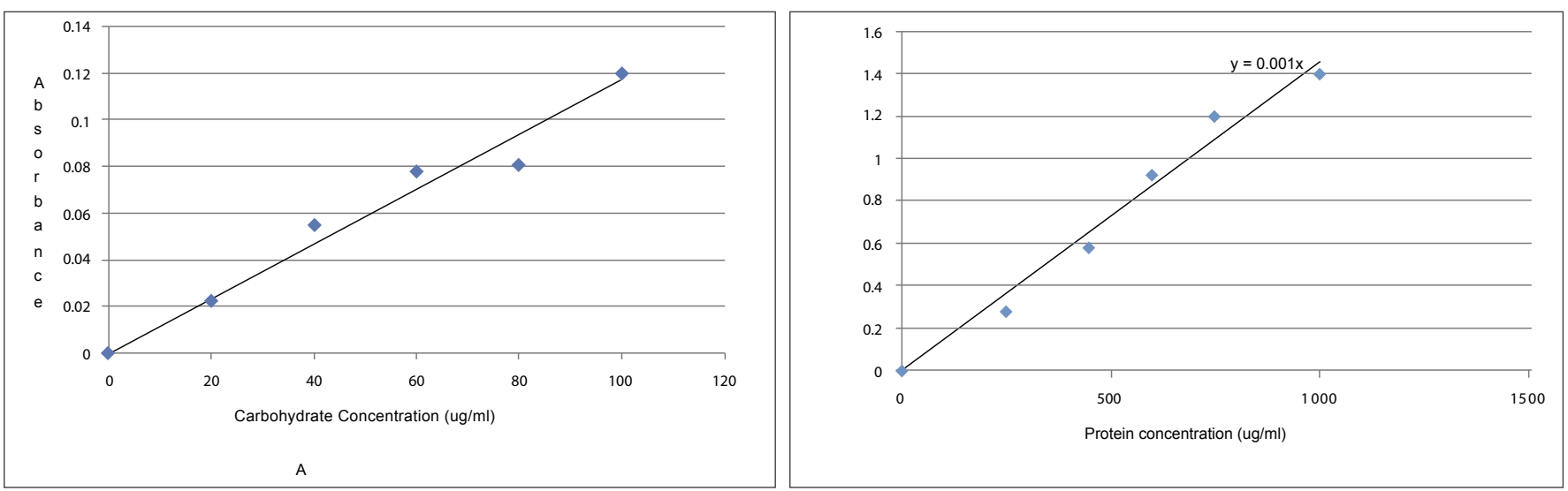

soxhlet apparatus is $2.04 \mathrm{gms} / 100$ gms. The mineral analysis using Atomic absorption spectroscopy, shows Iron $(\mathrm{Fe})-0.116 \mathrm{mg} / 1 \mathrm{~g}$, Zinc (Zn)-0.01mg/1 g, Nickel (Ni)-0.048 mg/1 g, Copper (Cu)-0.05 mg/1 g, Calcium (Ca)-0.05 mg/1 g and Phosphorus (P)-0.11 mg/1 g. And crude fiber of seed coat is estimated to be $13.08 \mathrm{gms} / 100 \mathrm{gms}$. The complete proximate analysis is plotted in table 1 .

\section{Phytochemical analysis}

In the qualitative analysis of seed coat found, Terepenoids, Alkaloids, Gums and Saponins, but it indicated the presence of Starch, Protein, Glycosides, Phenolics and Flavanoids. The detail study is given table 2.

The quantitative analysis of the phenolics using shows the total phenolic content present is found to be Folin-Ciocalteu method is found to be $2.12 \mathrm{mg} / \mathrm{gm}$, as shown in the figure $2 \mathrm{~A}$, and total flavanoids by Quercetin equivalent is found to be $1.3 \mathrm{mg} / \mathrm{gm}$, as shown in the figure $2 \mathrm{~B}$.

\section{Conclusion}

The proximate analysis of the seed coat gave an idea for its chemical composition, which has significant amount of fiber and carbohydrate. The protein content is also considerable in preparing the enzyme assay for the removing the seed coat. These preliminary studies will be even helpful in comparing the nutrient properties of the seed, without seed coat after enzymatic treatment. Based on this proximate and phytochemical analysis, it would easy to design an optimal cocktail of enzyme assay that can break the seed coat, which allow processing the seed coat from P. sumantranse. For example, the fiber is the one of the major component in the seed coat. The proximate analysis shows $13.08 \%$ of fiber content. From this study, the composition will help in designing an optimal enzyme assay, which can hydrolyze the fiber content and help in seed coat processing. Similarly, we have got chemical composition of proteins, carbohydrates and fats, which forms the major part of the seed coat. Our aim is to design an optimal cocktail of enzyme assay, based on the above chemical compositions, which can break seed coat and help in processing the seed coat, by retaining the original properties of the seed as such. In this study, we have considered little millet from Javadhu hills, Tamilnadu, as only source because the plant is majorly grown only in this area of Tamilnadu. Later, once we designed the prototype of this technology using this source, we would like to optimize technology, but collecting more samples from other states of India, although, the little millets grow in similar conditions.

Figure 1: A) Carbohydrate standard graph using phenol sulphuric method at $510 \mathrm{~nm} \mathrm{B).} \mathrm{Protein} \mathrm{standard} \mathrm{graph} \mathrm{using} \mathrm{Lowry's} \mathrm{method} \mathrm{at} 600 \mathrm{~nm}$. 
Citation: Dangeti SR, Karthikeyan S, Kumar GR, Desai S (2013) Proximate and Phytochemical Analysis of Seed Coat from P. sumantranse (Little Millet). Biochem Anal Biochem 2:134. doi:10.4172/2161-1009.1000134

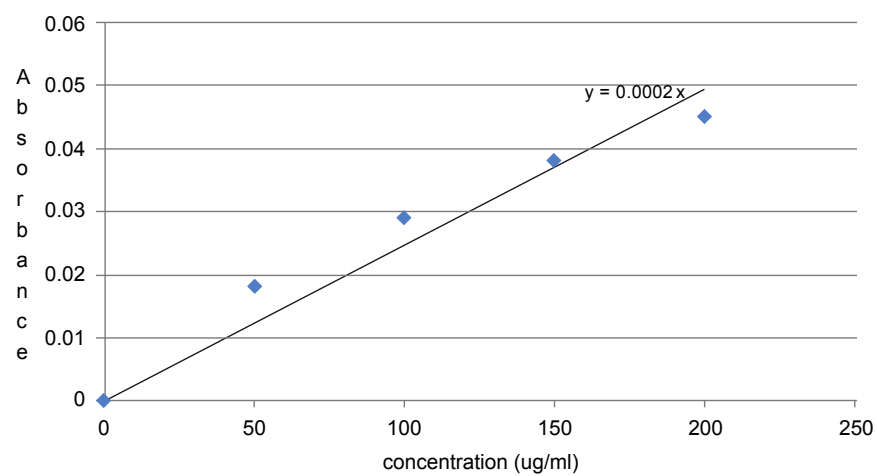

A. standard graph for flavonoids

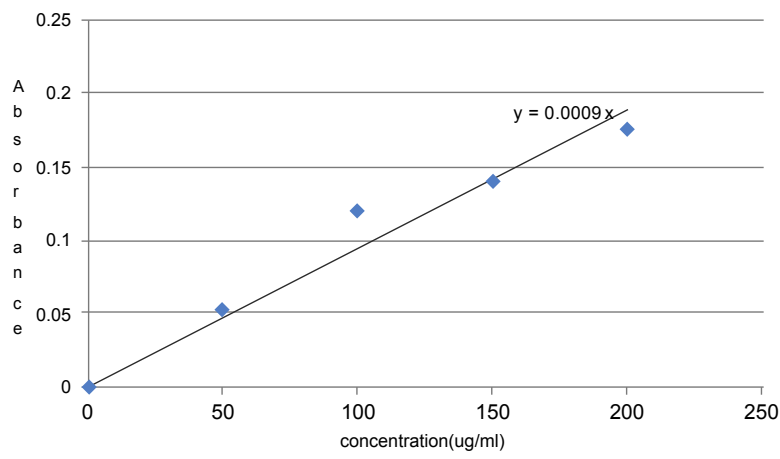

B.standard graph for phenolics

Figure 2: A. Total flavanoids content by Quercetin equivalent method. B. Total phenolics by Folin-Ciocalteu method.

\section{Acknowledgement}

We take this opportunity to extend our word of thanks and express our gratitude towards our guide Mr. S. Karthikeyan (Asst Professor Senior), School of Bio Sciences and Technology (SBST), VIT University, Vellore, Mr. R. Balaguru (Ph.D) and Mr. Babu, In-charge of Centre of Social And Rural Development, VIT University, Javadhur Hills for offering us their invaluable guidance, constant encouragement, extensive suggestions and freedom in all aspects during the entire tenure of this work. We are grateful to them for their personal interest, attention and care shown towards us while undertaking this project, and guiding us towards a bright and prosperous future.

\section{References}

1. Seetharam A, Riley KW, Harinarayana G (1986) Small millets in global agriculture. Proceedings of the First international small millets workshop, Bangalore, India.

2. Saunders RM, Connor MA, Edwards RH, Kohler GO (1972) Enzymatic processing of wheat bran: effects on nutrient availability. AACC 49: 436-442.

3. Pearson D, Henry EC (1976) The chemical analysis of Foods. (7th Ed.), Church-Hill, Living Stone, London, UK 487-497.

4. Paquot C (1979) Standard methods for the analysis of oils, fats and derivatives. (6th Ed.) Part I (Sections I and II) Pure and Appl Chem 51: 2503-2525.
5. Lowry OH, Rosebrough NJ, Farr AL, Randall RJ (1951) Protein measurement with the folin phenol reagent. J Biol Chem 193: 265-275.

6. Okezie OB, Bello AB (1988) Physico-chemical and functional properties of winged bean flour and isolate compared with soy isolate. J Food Sci 53: 450454.

7. Olayanjo TMA (2004) Beniseed: A big treasure in small capsule. Publication in RMRDC. Raw Material Upgrade Magazine, Abuja, Nigeria.

8. AOAC (1995) Official methods of analysis (References: 922.06, 991.20, 923.03 and 978.10). Association of Official Analytical Chemists.

9. Kujala TS, Loponen JM, Klika KD, Pihlaja K (2000) Phenolics and betacyanins in red beetroot (Beta vulgaris) root: distribution and effect of cold storage on the content of total phenolics and three individual compounds. J Agric Food Chem 48: 5338-5342.

10. Shiva M, Mohammad S, Manoochehr H, Yaghoub A, Seyed ESE, et al. (2007) Antioxidant power of Iranian propolis extract. Food Chem 103: 729-733.

11. Bandelier J, Chunching T, Olle M, Montet D (2002) Original study of the biochemical and oil composition of the cambodia nut Irvingia malayana. J Agric Food Chem 50: 1478-1482.

12. Mepba DH, Eboh L, Nwaojigwa SU (2007) Chemical composition and baking properties of wheat-plantain composite flours. African Journal of Food, Agriculture, Nutrition and Development 7: 1-21.
Citation: Dangeti SR, Karthikeyan S, Kumar GR, Desai S (2013) Proximate and Phytochemical Analysis of Seed Coat from P. sumantranse (Little Millet). Biochem Anal Biochem 2:134. doi:10.4172/2161-1009.1000134 